\title{
The independence referendum in Scotland: a tourism perspective on different political options
}

\section{Brian Hay}

Brian Hay is a Honorary Professor at the School of Management and Languages, Heriot-Watt University, Edinburgh, UK.
Received 28 May 2015

Revised 19 August 2015 Accepted 29 August 2015

(c) Brian Hay. Published in the Journal of Tourism Futures. This article is published under the

Creative Commons Attribution (CC BY 4.0) licence. Anyone may reproduce, distribute, translate and create derivative works of this article (for both commercial and non-commercial purposes), subject to full attribution to the original publication and authors. The full terms of this licence may be seen at http://

creativecommons.org/licences/by/ 4.0/legalcode

\begin{abstract}
Purpose - During the 2014 independence referendum in Scotland, there was much debate about the future broader political direction of the country but little discussion about its impact on Scottish tourism. The purpose of this paper is to explore and discuss the impact of the different future political options from a tourism perspective.

Design/methodology/approach - From the literature, four main political drivers were identified, and using Scotland as a reference, they were used in discussions with six experts to explore how tourism could develop under different political options. The outcomes from these discussions were combined by the researcher to develop in conjunction with the experts an agreed discussion note. This discussion note formed the basis for the exploration of the impact on tourism under four different future political options.

Findings - Of the four political options (devolution limited, devolution plus, devolution max/fiscal autonomy/ federation and full independence), it is clear that all options had different positive and negative impacts for tourism. The devolution max option, however, was perceived as most damaging to tourism, because tourism would not be considered a priority, relative to other policy issues. The study concludes with six key lessons that destination management organisations (DMOs) should contemplate when considering the impacts of different political futures. Research limitations/implications - Being focussed on one country with a strong political party whose raison d'être is independence makes it difficult to extrapolate the results. Nevertheless, given the strong commonality of agreement of the impacts within the experts consulted, this study suggests that DMOs can and should engage in political debates about the future of tourism in their destination.

Originality/value - The 2014 independence referendum in Scotland failed to achieve its primary aim of independence for Scotland, but it did provide space for other political options to be explored. This paper provides a perspective on how tourism could develop under different political options, and so help raise its profile in any future debates, both in Scotland and other destinations.
\end{abstract}

Keywords Tourism, Politics, Scotland, Futures, Secessionists movements

Paper type Research paper

\section{Introduction}

Although Scotland is a small country, it has been at the forefront of tourism futures' thinking through the use of scenario-planning as a tool in developing its tourism sector and in establishing the world's first scenario-planning team within VisitScotland, the national tourism marketing organisation for Scotland. Yet, from the first tentative report making use of scenario-planning in Scotland (Price, 1999), which was driven by the first serious debates about devolution, discussions about the implications for devolution/independence have not really appeared in the scenario-planning reports emerging from VisitScotland nor in industry discussion papers about the future of tourism in Scotland. Indeed, in the most recent reports about the future of tourism in Scotland written by the 
main industry organisation, the Scottish Tourism Alliance (2012), and by the publicly funded futuresfocussed organisation, Tourism Intelligence Scotland (2014), neither mentioned the issue. What little research that has been published on the impacts on tourism of the referendum of September 2014 has been weak, lacks consensus and is inconclusive, and despite the rejection of independence by the people of Scotland, there still remains "much concern among industry stakeholders about the future of the Scottish tourism product" (Cuffy and Danby, 2014, p. 6).

The issue of devolved power is not unique to Scotland: within Europe, there are the German Laenders, Spanish autonomous communities, the regions of Belgium and the provinces of Northern Italy, and their secession movements have all explored the need for more devolved powers. As Wagstaff (1999) has noted, the member states of the European Union (EU) have for the most part not experienced any major political, ethnic or religious strife in recent years. This is not to say that there have not been problems in parts of Europe, for example, in Northern Ireland and in the former states of Yugoslavia, and in 2015, in Ukraine. However, in recent years, along with the expansion of the EU, there has developed the twin tracks of increasing centralisation of power at the European level and the demand for more control at the local level. In an effort to counter the impact of centralisation, there is a requirement enshrined in the 1993 EU Maastricht Treaty known as "subsidiarity", which is based on the concept that nation states rather than the EU are best suited to deliver services to their people. Often the responsibility of implementing EU legislation falls to the myriad of regional governments (Keating, 2004). Also, unlike other major countries such as Australia, Canada, Switzerland and the USA, the peoples and the governments of Europe have not generally adopted the concept of federalism. However, there is a growing awareness of the increasing political strength of regional identity, and this has asserted itself through the demand for more local control of decisions. There is nothing new about this demand for local political control, and in Scotland, it can be traced back to the mid-1960s, when a combination of regional economic decline, disaffection with the dominant political party (Labour), the revival of strong regional development policies and public investment in large infrastructure projects helped to increase awareness of the advantages of local control. The election in 1967 of the first Scottish National Party (SNP) member to the UK Parliament is a reflection of this demand.

\section{The four key political drivers of change in Scotland}

\section{Political driver 1}

The above structural economic indicators, whilst important, are insignificant when compared to five key political events. In 2011, the SNP gained overall control of the Scottish Parliament; in September 2014, there was the referendum on whether Scotland should remain part of the UK or become a separate country; in 2015, there was a UK-wide election; in 2016, there was a general election for the Scottish Parliament; and in 2016, there will be a referendum on whether the UK leaves or remains a member state of the EU. Of these five events, the first four have already occurred; in 2011, the SNP gained control of the Scottish Parliament; in 2014, the people of Scotland, on an 85 per cent turnout, rejected independence by 55 to 45 per cent, with the voters in 29 of the 32 local government areas also rejecting independence. What was interesting, however, was the subsequent upsurge in support for the SNP, whose membership grew from 25,000 in 2013 to over 100,000 in 2014 (Keen, 2015), making it the largest political party in Scotland, despite being defeated in the 2014 independence referendum. This popularity carried over to the 2015 UK Parliamentary general election, in which the SNP gained 56 out the 59 Scottish seats to become by far the largest political party in Scotland and the third largest in the UK Parliament. This is the first issue to note in terms of political drivers - the development of a popular regional political party, with the welfare of its people at the heart of its policies.

\section{Political driver 2}

As part of the preparations for the independence referendum in 2014, the Scottish Government (2013) published a 650-page report with 390 references, setting out the case for independence, along with detailed arguments on how the various industries in Scotland could grow as a result of independence. In this report, there was almost a complete lack of discussion on tourism, despite it being noted as one of the key economic drivers for Scotland. In terms of other discussions in the 
wider academic and popular press about the possible impact of independence on tourism, they were limited to some negative references in the popular press as to whether English tourists would still be welcome in Scotland. The tourism industry, however, had real concerns which were reflected in the only public debate about tourism, organised by the Scottish Tourism Alliance in June 2014. These concerns were not about the principles for or against independence but focussed on hygiene issues such as border controls, passports, currency and labour contracts. This debate at which the main political parties, along a few academics, spoke about the issue ended in a vote in which the audience (mainly tourism businesses) rejected independence by over 90 per cent.

There is nothing new about the growth of independence movements; over the centuries, states have been formed, merged and dissolved; the concept of a sovereign state with defined boundaries is a relatively new development. Since the end of the Second World War in 1945, many countries have gained their independence; for example, the UK ceded independence to almost 50 countries, from India in 1947 through to Hong Kong in 1997. Over the past 100 years in Europe, we have seen new countries granted independence, such as when Norway split from Sweden in 1905 and the dissolution of the USSR in the 1990s, which led to the emergence of the Baltic States and others such as Ukraine. Even later, Czechoslovakia was split into two countries, and new states such as Montenegro and Serbia were formed when Yugoslavia was dissolved. Outside Europe, perhaps the best known secessionist movement is the Canadian Parti Québécois, which failed in two referendums to gain enough public support to leave the Canadian Federation.

Although Europe is often considered to be a stable political environment, over the past decades, there has been an upsurge in the demand for more power to be devolved from national government to regional government (often labelled as nationalism) and even calls for the demise of the nation state (labelled as separation). As Cody (2012) has noted, there has been in Europe a recent growth not only in nationalist movements but also in separatist movements, driven by the recession in a number of European counties; he has also noted that the "old demons of regional separatism have surged anew, raising another unwelcome challenge to the Continent's traditional nation states" (p. 23). Examples of growing demands for recognition include the New Flemish movement in Belgium and the Basque and Catalonia regions in Spain, although the demand for more recognition in others regions have faded, such as Corsica from France and the Northern League in Italy. In conjunction with the emergence of different political structures, the people of Europe are becoming much more physically and socially mobile. With the free movement of people across the EU, along with the emerging trend of a mobile workforce (Elliot and Urry, 2010), the idea of living and working only in one country is seen as obsolete, as is the concept of allegiance to a single nation state. This emerging irrelevance of the nation state and the demand for local control of decisions is the second issue to note, in terms of political drivers. As Attali (2009, p. 180) has noted "more than a hundred new nations could be born this century".

\section{Political driver 3}

Scotland has four major political parties: Scottish Conservative and Unionist (right leaning), Scottish Labour (left leaning), Scottish Liberal Democrats (centralist)-all of which can be described as pro-UK unionist parties-and the SNP (left leaning), the sole major pro-independence party. With the rise in the popularity of the SNP in the 1970s and 1980s, there was a growing pressure on the Unionist parties to work together (Pittock, 2008), and this was manifested in the idea of devolving limited political power from the UK Government in London to Scotland. The people of Scotland rejected devolution in the first referendum in 1979, and in the UK election that year, the SNP gained only two seats, and, therefore, independence for Scotland was no longer on the UK political agenda. For the next 18 years, the Conservative Party was the major party in the UK Parliament, in what became known as the "Thatcher Years". Over this period, Scotland experienced major changes in its industrial structure, such as the closure of its steel-making facilities and many of its coal pits, a rapid decline in the number of ship-building yards, high levels of unemployment and the imposition of what became known as the "poll tax" (a uniform tax on each adult in Scotland, which was perceived as a precondition of the right to vote). 
In the 1997 UK election, a Labour Government was elected, and with the Conservatives holding no seats in Scotland, the scene was set for another referendum; in 1997, 74 per cent of Scottish voters opted for devolution. In 1998, a Scottish Parliament along with a Scottish Executive (a supporting civil service) was established, with powers over a wide range of activities such as health, justice, housing, rural affairs, transport and economic development, including tourism (Scottish Government, 2012). Since the first Scottish Parliament election in 1999, there has been a gradual shift in political power from Scottish Labour as the major political party to the SNP, and in the 2011 election, the SNP gained overall control of the Scottish Parliament; they included in their manifesto a commitment to hold a referendum on Scottish independence (Scottish National Party, 2012). It was to be a clear choice of either a "Yes" or "No" to independence, with no third option such as an increase in devolved powers. The referendum was designed to provide a clear statement of what would be become known "as the settled will of the people of Scotland, providing a once-in-a-generation opportunity" (Lockhart, 2014, p. 1). Therefore, the third political driver is the election of the dominant political party with the determination to hold a vote on independence but failing to gain popular support for independence.

\section{Political driver 4}

The quality and the openness of the independence debate in Scotland was interesting; one impact was an increase in awareness among the Scottish people of politics and political issues in Scotland. The very high turnout of 85 per cent of the eligible population was welcomed across the political spectrum, as was the expansion of the franchise to 16 and 17 year olds. But there was also discontent, because Scots living in other parts of the UK as well as overseas were not allowed to vote, while immigrants in Scotland from other parts of the EU, including England, were allowed to vote. There was some discontent in other parts of the UK, as any decision taken in Scotland would also impact the governance of the rest of the UK, but the rules for the implementation of referendum did not provide for people living outside Scotland to vote.

The two political groupings of the "Yes" and "No" vigorously debated the issues. There was, perhaps surprisingly, a part of the population who perceived the supporters of the "No" campaign to be anti-Scottish, and this resulted in some unpleasant confrontations. There was, however, a consensus that the referendum should be a once-in-a-generation opportunity and that it should be accepted as the settled will of the people of Scotland. This was clearly stated by Alex Salmond, the leader of the SNP, and the then First Minister (Lockhart, 2014), but since then, there has been much debate as to whether the issue will appear in the SNP manifesto for the 2016 Scottish Parliament elections. There is also the possibility of a series of referenda until the SNP gain a "Yes" vote for their objective of independence; this has been labelled a "neverrendum", because the "Yes" movement has to win only once, while the "No" movement has to win every time. This issue has also arisen in Quebec, where, despite two referenda rejecting independence, there is still a strong movement for another referendum. The suspicion in Scotland is that there is likely to be another referendum in the near rather than distant future. The fourth political driver is the ability to hold a free, fair and decisive referendum, and for all sides to agree to abide by the decision, and for this decision to be seen as the settled will of the people.

\section{Research methods}

As this study was essentially explorative, the selected research methodology involved debating with and cross-examining "expert interviewees" in order to provide insights into their understanding of the implications of the selected political drivers and the impacts of various emerging options associated with each of the political drivers on the delivery of tourism. As O'Gorman and Macintosh (2014, p. 2) noted, "research is essentially about the production of new knowledge", but this is a difficult claim to make for this study, as the research paradigm is difficult to elucidate, the sample is small and the discussions with the experts were essentially explorative in nature. As this study is about gaining a better understanding of the central issues that have an impact on the devolution/ independence debates and exploring these ideas in discussions with "experts", the research methodology could perhaps be best described as adopting an interpretive paradigm approach.

The limited number of experts who had detailed knowledge of tourism in Scotland and were also willing and able to think about future issues, whilst being able to reflect objectively on the impact 
of the referendum, and were willing to be interviewed during a closely fought UK election (May 2015) certainly created challenges for the methodology. Further challenges included a Government "purdah", which prevented public servants from taking part in discussions during the election, and the clear instructions from a number of Scottish universities to their staff, limiting their participation in open debates about devolution/independence.

The selection of the actual expert interviewees as the chosen sample was far from perfect, and it highlights the explorative nature of this paper. The experts were professional colleagues known to the researcher, but their individual political views on the independence debate were not known to the researcher; this is acknowledged as a limitation, but the quality and rigour of the one-to-one discussions did provide many deep insights. It was stressed by all the interviewees that they were offering personal rather than organisational observations, but the ability of the interviewees to distinguish between the two perspectives must be open to question. The interviews were conducted face to face in Scotland in April 2015, either in the interviewee's office or on a university campus (Table I). The interviewees were not remunerated, and none of those approached declined to be interviewed. Of course, there are limitations to all research methodologies, and the extent to which the selected experts were representative of the universe of experts is open to question. The one clear advantage, however, of using known professional colleagues is the high degree of respect and trust between the interviewer and interviewee. The pitfalls in selecting expert informants are well documented by Johnson (1990) and include, but are not limited to, manipulation of the researcher, protecting the experts' confidential comments and exploiting and deceiving the interviewees.

As Bryman and Burgess (1999) note, key experts can play a number of roles, all of which were performed by the experts in this study, namely, as a guide (suggesting critical topics to consider), an assistant (making available informal/ittle known documents), an interpreter (selecting and sifting important information and issues) and a historian (understanding the background development issues).

In terms of the research process, after selection, each expert was interviewed separately to assess, first, the suitability of the four selected political drivers derived from the background review and the researchers' understanding of the issues; second, they were asked to explore the various possible political options of devolution/independence derived from these four drivers; and finally, to explore the likely implications of how tourism could develop within each of these options. After bringing together their collective thoughts and searching for areas of commonality, a draft note of the outcomes of their combined thoughts was circulated to each of the experts in order to seek their support of the researcher's interpretation of their insights. Following comments on this first note, a revised note was circulated, where agreement was reached about the main issues, which was used to develop this paper.

\section{Discussion of the various political options and implications for tourism futures}

As Hay (2013) has outlined, there are a number of possible options facing a country when they are considering different degrees of autonomy, and each of these options may provide for a different operational model in how the destination management organisation (DMO) could

Table I Description of experts interviewed

\begin{tabular}{|c|c|c|}
\hline Type of organisation & Job description & Experience \\
\hline $\begin{array}{l}\text { Commercial research } \\
\text { consultancy }\end{array}$ & $\begin{array}{l}\text { Senior tourism } \\
\text { consultant }\end{array}$ & $20+$ years in consultancy, mostly but not all in tourism \\
\hline Public sector (tourism) & Tourism researcher & Relatively new to public sector, but extensive experience ( 15 years in private sector) \\
\hline Private sector (hospitality) & Managing director & Over 30 years working in hotel management in the UK and also overseas \\
\hline University & Professor & $\begin{array}{l}20 \text { years of tourism experience, and also works as freelance consultant on Scottish } \\
\text { Government contracts }\end{array}$ \\
\hline UK/Scottish Government & $\begin{array}{l}\text { Senior economic } \\
\text { advisor (retired) }\end{array}$ & $\begin{array}{l}25+\text { years as an senior Scottish/UK Government Economic Advisor on a wide range of } \\
\text { studies, including transport and tourism }\end{array}$ \\
\hline European Union & Policy advisor (retired) & $\begin{array}{l}\text { Extensive experience (30+ years) working in Brussels for the EU on a number of issues, } \\
\text { including regional policy issues }\end{array}$ \\
\hline
\end{tabular}


manage their tourism product. As confirmed by the expert interviews, apart from the status quo, there are four possible political options (Table II).

To avoid confusion in the terminology, for the purpose of this paper, a host DMO is used to describe a country-wide DMO such as VisitBritain, while a regional DMO is used to describe a DMO operating in only one part of a country such as VisitScotland, even though Scotland is a country.

\section{Future political option 1: devolution limited, with organic change}

Under this option, as a region evolves, changes to its political structures tend to be slow and organic. There will be communication between the host $\mathrm{DMO}$ and the devolved regional $\mathrm{DMO}$, as in Scotland, where marketing staff from both VisitBritain and VisitScotland worked together, for example, on marketing campaigns of mutual interest, and where the chairs of the boards of the two bodies acted as political touchpoints. It is unlikely in this option that any one part of the country would have the ability to raise its own taxes, such as a bed, tourism or convention tax, because there would be strong support for uniform tax rates across the whole country in order to prevent one part gaining a tax advantage over another part, by, for example, reducing sales tax on hotels. It is very likely that the regional DMO would be funded from either general taxation distributed through the regional political structures/organisations, or, but less likely, by the host-country DMO. It is possible that the regional DMO would focus on marketing within its own region and to other parts of the country, i.e., within Scotland and within the UK, but would leave most overseas marketing to the main DMO.

The regional DMO within this limited devolved option, if it is funded directly by the regional government, may be more aware of regional political issues and may even seek to undertake some in-destination, politically focussed marketing to stress its own importance, because it will need to compete with other publicly funded activities for limited public funds. The DMO's relationship with the private sector will continue to develop as it becomes aware that it cannot achieve its goals without support from those delivering the product (accommodation, transport, activities, etc.). Under this option, the concept of public-private partnership may become stronger, with regionally based businesses now directly influencing the strategic direction of the regional DMO. In reality, probably little will change in terms of marketing priorities, the exception being a re-focussing of marketing to include marketing of the DMO's destination to its own people, so as to encourage them to holiday in their own country. This may result in an increase in visiting friends and relatives tourism in the area. Also, there may be more sponsorship of local events and perhaps more direct contact with local people to explain the importance of tourism for the region, and so help to reinforce the need for a regional DMO.

\section{Future political option 2: devolution plus}

Although under this option there may be some additional but limited tax-raising powers for the devolved government, they will be few and limited, and the regional DMO will probably be fully

Table II Levels of autonomy and possible DMO structures

Level of autonomy Key political drivers

Devolution limited, The development of a popular regional political party, with with organic change the welfare of its people at the heart of its policies

Devolution plus for more local control of decisions

Devolution max/ fiscal federation/ fiscal autonomy Full independence

The election of the dominant political party with the determination to hold a vote on independence but failing to gain popular support for independence

The ability to hold a free, fair and decisive referendum, and for all sides to agree to abide by the decision, and for this decision to be seen as the settled will of the people
Emerging tourism management structures

A regional DMO with limited freedom, always seeking to work with the host-country $\mathrm{DMO}$, particularly in joint marketing campaigns. This DMO tends to focus on domestic and near-country markets

d A regional $\mathrm{DMO}$ with the ability to work freely within an agreed set of fairly wide and relaxed controls that have been agreed with the host-country DMO

A more or less independent DMO with limited working

arrangements with the host $\mathrm{DMO}$, free to work in markets that best suits its products and priorities

$\mathrm{DMO}$ acting in the best interest of the newly independent country, which is seen as an equal partner alongside other DMOs, especially the former host-country DMO 
funded by the devolved government and receive no funds from the host DMO. It is unlikely to involve any one region varying the levels of taxes so as to give them an economic advantage over other regions. Therefore, the provision of direct tax-raising powers is unlikely, but under this option, the regional government will have much more responsibility for the management of a wide range of existing services. In Scotland, this includes responsibility for education, transport, health, social welfare and inward investment. Whatever the powers of any devolved authority, there will likely be a much more direct relationship between the raising of taxes and the resulting expenditure on services, including tourism.

One of the clear future trends in most Western European countries is that of a growing population of older people, which will require an increasing expenditure on social services; given the high costs of providing such services (public health, social services, welfare and pensions) and the political necessity of protecting them from budget decreases, it is likely that this policy will impact non-essential services such as tourism, where budgets may well be cut. Also, given the assumption that one part of a country would find it politically difficult to offer a lower level of such services than other parts, it is likely that under this political option, budgets for non-essential functions will be squeezed. After the "No" vote in the Scottish Referendum in 2014 and following several years of budget increases, the regional DMO in Scotland has had its budget frozen, and what additional funds that were allocated have been ring-fenced for specific activities by the Scottish Government (VisitScotland, 2014). Budgets for organisations funded by the Scottish Government have been increasingly subject to much more ring-fencing, i.e., budgets for organisations are being made conditional on achieving Scottish Government targets. In this option, there is likely to be a high degree of micro-management by the devolved government in the delivery of local functions. It is also possible that the regional DMO will begin to lose its independence and be subject to not only more management control but also more political control by the devolved government. The logical outcome of this action can be seen in Wales, where tourism, instead of being managed by an independent $\mathrm{DMO}$, was transferred into the Welsh Government structure.

In Scotland, it is an oxymoron that with increasing devolution came more central control of traditionally devolved functions. For example, since the SNP took control of the Scottish Parliament in 1996, there has been the merger of eight police authorities into one organisation (Police Scotland), the merger of regional Fire and Rescues Services (Fire and Rescue Scotland), the 21 local economic development/enterprise companies merger into two organisations (Scottish Enterprise and Highlands and Islands Enterprise), the merger of local technical colleges into regional colleges and, in tourism, the merger of 14 local area tourist boards into one already existing organisation (VisitScotland).

Given that budgets are likely to be restricted, out-of-country marketing for the region will rely more on the national $\mathrm{DMO}$, as the costs of such marketing may be too expensive for the regional DMO. It is also possible that the larger private-sector companies based in the regional DMO area will look to the national DMO for leadership, so the regional DMO may lose influence over local businesses, as they opt to support national DMO marketing campaigns rather than regional DMO campaigns.

It is also likely in this option that the public may question the rationale of the funding model for the regional $\mathrm{DMO}$, where most of its funds are provided by general taxation. It is possible that they would ask why, when public funds are limited, they should support an activity that is designed for visitors rather than for the benefit of residents, although it could be argued that such support is good for local tourism businesses.

\section{Future political option 3: devolution max/fiscal federation/fiscal autonomy}

This option, commonly known as devolution max, is about as close as possible for a country to be independent, without actually being independent. It is likely, as has been suggested in Scotland, that the region would take full control of the raising all taxes and of all spending within its borders for all the services it provides (fiscal autonomy), with the exception of externally facing functions, such as foreign affairs and defence (Bowditch, 2015). There would be no internal border controls with the host country and no need for separate passports, and there would be continuation of a common currency, all of which would help tourism by maintaining the benefits of a national tourism product. 
With control of its own taxes and spending (fiscal federation), there could be a call for the adoption of differential taxes from other parts of the host country and the creation of new taxes such as a bed tax, which, if hypothecated, could be used to fund the regional DMO, rather than relying on public funds. It could be argued that the regional DMO could be removed from public control and be managed through a different model, such as a public-private corporation.

The issue of tax-variation powers and, in particular, tax-reduction powers, has wider implications than just within the region using such powers, because their use might be perceived as anti-competitive by neighbouring political entities, which may not be able to match these tax reductions. National governments may resist proposals to grant such powers to any devolved administration on the grounds that they could disrupt its wider regional development policies, particularly with regard to social welfare and the wider benefits for society derived from what most countries would regard as an essential function, that of a redistributive/fiscal equalisation tax policy.

It is possible that the regional DMO would chose to adopt a different marketing strategy from the host-country DMO, by establishing its own tourism marketing offices in overseas countries. Although such offices could co-exist with those of the host $\mathrm{DMO}$, it is very likely that the regional DMO would want to establish its own independent offices. An alternative model would be to share overseas offices with like-minded counties, e.g., Scotland with Ireland, although there may be a competition issue to overcome. However, given the innovative marketing opportunities offered by social media and the new methods tourists use to source information, establishing overseas offices could be more a vanity project and a statement of liberation rather than an absolute necessity. It is unlikely in this option that the regional DMO could become a member of international organisations such as the European Travel Commission or the UNWTO.

In this option, relations between the regional DMO and the private sector are likely to be very positive, as they may perceive that the devolved government would be much more proactive and in control of its own future, mainly through the ability to raise taxes and to set spending priorities. It is likely that a tourism tax would be introduced, with an assumption that the income generated would be used to support the regional DMO. It is also possible that the income could be used for other purposes, such as to subside a ferry route or as an incentive for marketing new air routes. It could also be used for improvements to the physical product, by assisting in the development of new hotels or attractions, or used to support the creation of other new political entities, such as tourism business improvement districts. Indeed, under this political option, there could be a re-examination of the role of the regional $\mathrm{DMO}$, from a tourism marketing focus to a tourism management focus, i.e., the DMO would need to embrace a much wider set of functions than just marketing.

There is a possibility that the various country-wide tourism professional societies and organisations might experience a demand for a more autonomous regional structure, which would have only a loose attachment to existing professional national bodies. It is not clear if these new regional societies and organisations would have the same level of power and access to the political gatekeepers as the existing national organisations.

\section{Future political option 4: full independence}

For many in the independence movement, this is the only option, and it is assumed that were independence to be achieved, there would initially be a huge amount of publicity, which would have an immediate positive impact on the tourism sector. However, independence will not happen overnight; it will take a number of years and will involve many detailed discussions, because everything from splitting the national debt to sharing the defence assets would need to be agreed by both sides. Given the enormous significance of these issues, it is doubtful if discussions on the future management of tourism would take priority. However, in the recent debates in Scotland about independence, although tourism was not really a central topic, issues relating to tourism were subject to much discussion, such as passport control, common currency, border controls and the Schengen Agreement (which the UK has opted-out of), which allows for the free movement of people within Europe. 
Such discussions were not limited to internal issues but also focussed on Scotland's membership of international organisations, such as the United Nations, the European Union, NATO and the International Monetary Fund, and the adoption of the Euro, the common currency for EU states. It was thought likely that Scotland's membership of such organisations would be fast tracked, but full recognition would not happen quickly, because rigorous procedures would need to be followed. Progress on these issues would be dependent on the outcome of the discussions in the period leading up to formal independence. Putting aside the issue as to whether Scotland would be regarded as a new member of these organisations, because the UK is already a member, the issues previously mentioned (passports, currency, border controls, etc.) would all have an impact on tourism in Scotland. For example, membership of the Euro, like all issues, could be negotiated; although the use of the Euro is required of all new EU members and is central to the concept of a united EU, it is likely that new countries such as Scotland would have to commit only to join the Euro at some vaguely defined date in the future, rather than as an immediate condition to be achieved by the date of entry into the EU.

Of much more concern is the free movement of people across the European Union, which is at the heart of an open Europe. The UK is already a member of a Common Travel Area (CTA) with Ireland, which means that passports are not required for travel between the two countries. If Scotland were to join the European Union CTA (the Schengen Agreement), which all the new EU countries admitted to the EU after 2004 are required to do so, this would prove difficult. Travel from its largest tourism market (England) would become problematic because England is not part of the Agreement. It would mean that a German citizen flying from Berlin to Edinburgh would not need a passport, but an English citizen travelling by train from London to Edinburgh would be subject to checks at the border. Given the importance of the English market to Scottish tourism, it is unlikely that Scotland would join the Schengen Agreement without some special dispensation from the EU. As with the Euro, it is likely that the EU would adopt a pragmatic approach and allow Scotland to temporally opt out of the Agreement. This discussion highlights an issue for other countries that although tourism may not be a central consideration in their independence debates, there are many hygiene issues (others include flight transfers, levels of duty/taxes and cross-border ownership of tourism facilities by companies) that would impact the travel and tourism sectors and need to be taken into consideration in any discussions.

One of the issues generating much debate across Europe is that of migrants, as many countries with a strong, but seasonal, tourism product rely on temporary workers from outside their borders. Working overseas, in fact, is often regarded by workers as necessary in order to progress in the hospitality and tourism sectors. The development of a guest-worker programme and the need for guest-workers' visas is perceived as essential to the development of tourism in newly independent countries.

On the positive side of independence, it is likely that air transport will experience new demands from overseas visitors, who would expect direct flights to the new country rather than transferring through a hub in another country. It is also possible that there would be an increase in the number of people from England visiting their friends and relatives in Scotland, because Scotland could be seen as a "foreign" country. There could also be an increase in business tourism, because businesses may have to negotiate new contracts and develop new cross-border client relationships. Conference and exhibition tourism could also be expected to increase in value, because the new country may be perceived as a new and even exotic destination.

\section{Key lessons for DMOs}

1. DMOs should not be afraid to take part in the political debate on the future government of their destination, because they have a public responsibility to explain the consequences for the tourism sector of selecting any particular form of new government.

2. Whatever form of future government is selected, the nature and power of the political relationships between the government entities will change, as will the relationship between 
the different public and private sector tourism organisations. Once the possibility of political change becomes an established reality, there is no going back to previous political models, for, as Davis (1999, p. 3) noted, "devolution is a process, not an event".

3. The transfer of funds and resources between one part of a country and another is a key unifying policy in most countries, and this policy of "social welfare unionism" (McLean et al., 2013) ensures that, in tourism, those DMOs that are perceived to need more support are given relatively more funds than the other DMOs. If devolution means that this policy would then be open to question, this could result in the adoption of a different funding model. DMOs should, therefore, be aware that there could be changes in their funding.

4. At the trans-national level, there could also be a realignment of regional tourism political power, with the smaller countries/regions and their emerging DMOs working together and supporting each other, leading to the waning of the political power of the larger country DMOs.

5. Particularly with the devo-max option, the new competitor for public funds to support tourism would be the demand for increases in the provision of social welfare services rather than other leisure services. DMOs would need to show that their operations could result not only in an increase in the number of tourists, but will also contribute to its residents' overall social well-being.

6. The more a region takes control of its tourism product, the more likely there is to be a shift from a DMO focussing only on tourism marketing to a new focus on managing the whole tourism product, which means that the DMO would likely be required to provide a full range of services to support its tourism sector and not just marketing.

\section{Conclusions}

Is the independence referendum in Scotland the first sign of a paradigm shift in disruptive behaviour that is upsetting the normal political processes in Europe, which could lead to profound changes in the management of its tourism products? Certainly in post-devolution politics in Scotland, there has been, as Cairney and McGarvey (2013) noted, a shift and a focus on the "new Scotland", which in economic terms has been dominated by the service sector such as ICT, renewable energy, retail, financial services and leisure and tourism, and a shift away from the traditional sector, such as heavy industry and manufacturing. In this new paradigm, tourism will be in competition with these new services for skilled employees and governmentfunded support. This move away from the "old" to the "new" has also been reflected in tourism, where there has been a rejection of the "old" activities such as passive sightseeing tours in the Highlands to a more fluid mixture of city, short-break and activity-holiday focus, but such a shift is not unique to Scotland.

With increasing devolution, there is always a question of where does the road end - is it full independence or is it what Rosenau (1984) labelled as "cascading interdependence", with political decisions taken at all levels - regional, national, state, supra-national and global levels. There has also been an increase in awareness of the fact that decisions cannot be taken in isolation at one level without an understanding of their impact on factors at the other levels. In tourism, the key question is what level of power is best suited to deliver tourism. The answer is, of course, not only dependent on the level of devolution, but also on the spectrum of functions that the DMO is expected to deliver and on whether their role is focussed strictly on tourism marketing or on a much wider tourism management role.

It is widely recognised that travel and tourism are complex phenomena that are in a constant state of flux, with many unexpected and unforeseen influences emerging from the development of social, political, economic and technology trends. This, along with weak empirical laws, theories and hypotheses, which fail to explain even the most basic behaviour of tourists, let alone assist in understanding their needs and desires in the future, makes tourism futures an exciting activity to explore; perhaps, at some time in the future, it will be possible to understand and even explain tourist behaviours. However, as Postma et al. (2013) noted, we are at the beginning of this exploration. Perhaps recognising and understanding the political needs of different national 
groupings of people within a country and their drive to govern and manage their own destiny can help us to at least explain if not control one of the variables, and so enable us to better understand the future development of tourism.

The independence referendum in Scotland has opened up the debate on the wide range of issues that need to be explored and considered within the various future political models. It is hoped that this paper provides insights into some of these issues and that it will assist DMOs in understanding the many and complex issues and difficult questions they will face on a road that is not well travelled and has no clear destination. However, as often been quoted, perhaps the journey is more important than the destination; this certainly applies to the devolved powers/independence debates, as the tourism sector seeks answers to difficult questions.

\section{References}

Attali, J. (2009), A Brief History of the Futures, Arcade Publishing, New York, NY.

Bowditch, G. (2015), "Impose devo max, and the bean counters will be seeking magic beans", Sunday Times, London, 15 March, p. 9.

Bryman, A. and Burgess, R.G. (1999), Qualitative Research: Volume 1, Sage Publications, London.

Cairney, P. and McGarvey, N. (2013), Scottish Politics, Palgrave Macmillan, Hampshire.

Cody, E. (2012), Separatists Groups are Gaining Ground throughout Europe, Sunday Globe, Boston, MA, p. 23.

Cuffy, V. and Danby, P. (2014), "Life after the referendum”, Tourism, Vol. 160 No. 4, pp. 6-7.

Davis, R. (1999), Devolution: A Process Not an Event, Institute of Welsh Affairs, Cardiff.

Elliot, A. and Urry, J. (2010), Mobile Lives, Routledge, Oxon.

Hay, B. (2013), "Breaking up is hard to do! The future of tourism in Scotland under different possible political options", in Postma, A., Yeoman, I. and Oskam, J.L. (Eds), The Future of European Tourism, Stenden University of Applied Sciences, Leeuvarden, pp. 132-49.

Johnson, J.C. (1990), Selecting Ethnographic Informants, Sage, Newbury Park, CA.

Keating, M. (2004), “The United Kingdom as a post-sovereign polity”, in O'Neill, M. (Ed.), Devolution and British Politics, Pearson, Harlow, pp. 319-32.

Keen, R. (2015), Membership of UK Political Parties, House of Commons Library Standard Note SN/SG/ 5125, House of Commons, London.

Lockhart, K. (2014), "This is a once in a generation opportunity for Scotland", Daily Telegraph, 14 September, p. 1, available at: www.telegraph.co.uk/uknews/scottish-indepenedce/11095210v/Alex (accessed 30 April 2015).

McLean, I., Gallagher, J. and Lodge, G. (2013), Scotland's Choices: The Referendum and What Happens Afterwards, Edinburgh University Press, Edinburgh.

O'Gorman, K. and Macintosh, R. (2014), Research Methods for Business \& Management, Goodfellow Publishers, Oxford.

Pittock, M. (2008), The Road to Independence? Reaktion Books, London.

Postma, A., Yeoman, I. and Oskam, J. (2013), The Future of European Tourism, Stenden University of Applied Sciences, Leeuwarden.

Price, G. (1999), Scenarios for Scotland - A Journey to 2015, University of St Andrews, St Andrews.

Rosenau, J. (1984), "A pre-theory revisited: world politics in an era of cascading interdependence", International Studies Quarterly, Vol. 28 No. 3, pp. 245-305.

Scottish Government (2012), "History of devolution", Edinburgh, available at: www.gov.scot/About/Factfile/ 18060/11550 (accessed 15 April 2015).

Scottish Government (2013), Scotland's Future: Your Guide to an Independent Scotland, Scottish Government, Edinburgh.

Scottish National Party (2012), Your Scotland, Your Future, SNP, Edinburgh. 
Scottish Tourism Alliance (2012), The Future of Our Industry in Our Hands: Tourism Scotland 2020, Scottish Tourism Alliance, Stirling.

Tourism Intelligence Scotland (2014), Scottish Tourism in the Future, Tourism Intelligence Scotland, Edinburgh.

Wagstaff, P. (1999), Regionalism in the European Union, Intellect Book, Exeter.

VisitScotland (2014), Board Minutes, VisitScotland, Edinburgh, November.

\section{Corresponding author}

Brian Hay can be contacted at: b.hay@hw.ac.uk

For instructions on how to order reprints of this article, please visit our website: www.emeraldgrouppublishing.com/licensing/reprints.htm

Or contact us for further details: permissions@emeraldinsight.com 